\title{
The Effect of High Elevated Temperatures on Nano Silica High Strength Concrete [NSHSC]
}

\author{
*K.I.M.Ibrahim \\ Construction Engineering Dept. , College of Engineering at Qunfudha, Umm-Al-Qura University- KSA on \\ Sabbatical leave from higher Institute of Engineering and Technology of Kafr-EL-shiekh - Egypt \\ Corresponding Author: K.I.M.Ibrahim
}

\begin{abstract}
The research aim is studying high elevated temperatures influence on NSHSC compressive strength . Effects of nanosilica (NS) content and several elevated temperatures [200, 400 and $\left.600^{\circ} \mathrm{C}\right]$ At 2 hours heat exposure time were studied. A constant water/binder equals to 0.40 and a constant binder content $=500 \mathrm{~kg} / \mathrm{m} 3$ were used. NS percentages that replaced cement in this study were 0,1\%,2\% and $3 \% .96$ cubes $10 \times 10 \times 10 \mathrm{~cm}$ were examined under compressive loads. They were divided as following, 24 cubes without (NS)as a reference and 72 cubes were cast to study NS content effect at several high temperatures. It was found that, at high elevated temperatures the NS content posses a large influence on improvement high strength concrete [HSC] performance.
\end{abstract}

Keywords: compressive strength- nanosilica and high temperatures

\section{Introduction}

It is significant to learn the concrete properties change owing to high elevated temperatures. To predict the structure performance after high temperatures exposure, it is necessary that the durability and concrete strength be understood[1]. high temperatures affect the concrete structures durability and may occur unwanted failures in structures. the concrete physical composition and concrete chemical composition change considerably at high temperatures exposure. Above 110 co Dehydration becomes significant. At 300c the matrix dehydration and aggregates thermal expansion cause internal stresses and micro - cracks begin to clear through the material. in cement paste $\mathrm{Ca}(\mathrm{OH}) 2$ is a main compound, dissociates at about 530 co, occurring concrete shrinkage of [2]. The elevated temperatures effects on durability and concrete strength are very important for studies of fire resistance and know pressure vessels, containment vessels, nuclear reactor ,chimneys performance, through service and maximum conditions structures such as storage tanks of hot water, crude oil and coal gasification. So that the differentiation of performance and compressive strength, are the main factors to be checked as concrete structures are exposed to high elevated temperatures[1]. HSC has several benefits ,it is used in the bridges construction and rise buildings [2]. The high temperature influences on the concrete properties have been checked since 1950s [3].Also, from 1950s HSC is made as god alternate for normal strength concrete (NSC)[4,5].HSC is produced using a decreased water/cement ratio. Commonly silica fume[SF] is also put in the concrete to improve the strength .Through exposure to elevated temperatures, concrete properties (volumetric stability, elastic modulus, and strength) are considerably reduced. When concrete structures are subjected to elevated temperatures, they may damage in many different ways [6].In addition, elevated temperatures will decrease [HSC and NSC] strengths. The strength reduction degree is dependent upon the temperature reached and the time of exposure [7,8]. Other factors which affect the strength loss are aggregate type and concrete strength [9]. Further, while exposure to elevated temperatures, concrete chemical composition and the physical structure change [10].The differences of behavior between[ NSC and HSC ]are observed in two important regions: (1) the strength relative loss in the average temperatures $\left[100{ }^{\circ} \mathrm{C}\right.$ to $\left.400{ }^{\circ} \mathrm{C}\right]$ and (2) the explosive spalling happening in HSC samples at similar temperatures. Strength loss studies have illustrated that, for average temperatures $\left[100{ }^{\circ} \mathrm{C}\right.$ to $\left.400{ }^{\circ} \mathrm{C}\right]$, the HSC compressive strength be decreased by about 40 percent of strength of room-temperature ,a decrease of approximately $20 \%$ to $30 \%$ points over NSC subjected to the similar temperatures. The HSC tendency for explosive spalling means that HSC structural elements may be more incline than NSC to loss the cover of concrete that gives the steel reinforcement by thermal protection[11,12,13,14]. 


\section{Materials}

Local materials are used and tested according to American Standard of Testing Materials ASTM and Egyptian Standard Specifications ESS in this study. Dolomite with maximum size $=19 \mathrm{~mm}$ and approximately angular shape was used. Natural sand was used as a fine aggregate in this search. Ordinary cement was used and its content equal to $500 \mathrm{~kg} / \mathrm{m} 3$ for all concrete mixes . Supper-plasticizer was used to give the water/ cement $=0.40$ with slump equals to $(6-11) \mathrm{cm} .$. this search used NS with content of solid more than $99 \%$, its content was $0 \%, 1 \%, 2 \%$ and $3 \%$ replacement from cement weight. The NS was brought from Nanotech Egypt. The color of NS was white, powder appearance, spherical shape, and average size $=56 \square 8 \mathrm{~nm}$.

\section{Concrete Mixes Proportions}

Mixes proportions are illustrated in Table (1.

Table (1): Concrete Mixes Proportions

\begin{tabular}{|c|c|c|c|c|c|c|c|c|}
\hline \multirow{2}{*}{$\begin{array}{c}\text { Mix } \\
\text { No. }\end{array}$} & \multicolumn{2}{|c|}{ NS content } & & \multirow{2}{*}{$\begin{array}{c}\text { Cement } \\
\mathrm{kg} / \mathrm{m}^{3}\end{array}$} & \multirow{2}{*}{$\begin{array}{c}\text { Dolomite } \\
\mathrm{kg} / \mathrm{m}^{3}\end{array}$} & \multirow{2}{*}{$\begin{array}{c}\text { Sand } \\
\mathrm{Kg} / \mathrm{m}^{3}\end{array}$} & \multirow{2}{*}{$\begin{array}{l}\text { Water } \\
\text { lit } / \mathrm{m}^{3}\end{array}$} & \multirow{2}{*}{$\begin{array}{c}\text { Super } \\
\text { plasticizer } \\
\mathrm{kg} / \mathrm{m}^{3}\end{array}$} \\
\hline & $\%$ & $\mathrm{~kg} / \mathrm{m}^{3}$ & & & & & & \\
\hline 1 & 0 & 0 & 500 & & 1133 & 567 & 200 & 9 \\
\hline 2 & 1 & 5 & 495 & & 1133 & 567 & 200 & 9 \\
\hline 3 & 2 & 10 & 490 & & 1133 & 567 & 200 & 9.25 \\
\hline 4 & 3 & 15 & 485 & & 1133 & 567 & 200 & 9.25 \\
\hline
\end{tabular}

Four mixes were used as follows, one mix without silica fume as a control mix, three mixes with different contents of (NS) to study NS content effect on the compressive concrete at high elevated temperatures . These mixes are identical except for the percentage of NS. For all samples, the binder content[ cement plus nanosilica] were $500 \mathrm{~kg} / \mathrm{m} 3$ and the water /cement equals to 0.4 by weight. Super - plasticizers per m3 were also used.

\section{Description Of Tested Specimens}

96 cubes $10 \times 10 \times 10 \mathrm{~cm}$ were cast for compressive strength .Concrete was poured vertically in the forms ,and was mechanically compacted to ensure complete compaction of concrete inside the forms. The samples were examined by using $2000 \mathrm{KN}$ compression machine.

\section{Test Results And Discussions}

table (2) and fig (1) show compressive strength results for all concrete mixes at room temperature the cement replacement by $1 \%, 2 \%$ and $3 \% \mathrm{NS}$ improves the 7and 28 -days compressive strength approximately $2 \%, 15 \%, 10 \%$ at 7 days and 3\%,16\%,6\% for 28 -days respectively. Table (3) and Figure (2) give compressive strength results of all concrete mixes at $200 \mathrm{Co}$, at 7 days age plain concrete[PC] compressive strength was 327 $\mathrm{kg} / \mathrm{cm} 2$ as was 328,365 and $352 \mathrm{~kg} / \mathrm{cm} 2$ for NSC with NS content $1 \%, 2 \%$ and $3 \%$ respectively with increase of about $1 \%, 12 \%$ and $8 \%$ with respect of PC, also for 28 days age, the PC compressive strength was 477 $\mathrm{kg} / \mathrm{cm} 2$ as was 536,549 and $532 \mathrm{~kg} / \mathrm{cm} 2$ for NSC of NS content $1 \%, 2 \%$ and $3 \%$ respectively with increasing of about $12 \%, 15 \%$ and $12 \%$ with respect of PC at the same temperature[200Co] . Table (4) and figure (3) give compressive strength results of all concrete mixes at $400 \mathrm{Co}$, at 7 days age the compressive strength of PC was $310 \mathrm{~kg} / \mathrm{cm} 2$ as was 325,338 and $369 \mathrm{~kg} / \mathrm{cm} 2$ for NSC with NS content $1 \%, 2 \%$ and $3 \%$ respectively with increase of about $5 \%, 9 \%$ and $19 \%$ with respect of PC, also for 28 days age , the compressive strength of PC was $422 \mathrm{~kg} / \mathrm{cm} 2$ as was 442,445 and $430 \mathrm{~kg} / \mathrm{cm} 2$ for NSC with NS content $1 \%$, $2 \%$ and $3 \%$ respectively with increase of about $5 \%, 6 \%$ and $2 \%$ respectively with respect of PC at the same temperature[400Co]. Table (5) and figure (4) give compressive strength results of all concrete mixes at $600 \mathrm{Co}$, at 7days age the PC compressive strength was $240 \mathrm{~kg} / \mathrm{cm} 2$ as was 281,269 and $303 \mathrm{~kg} / \mathrm{cm} 2$ for NSC with NS content $1 \%, 2 \%$ and $3 \%$ respectively with increase of about $17 \%, 12 \%$ and $26 \%$ with respect of PC, also for 28 days age the PC compressive strength was $300 \mathrm{~kg} / \mathrm{cm} 2$ as was 340,345 and $330 \mathrm{~kg} / \mathrm{cm} 2$ for NSC with NS content $1 \%, 2 \%$ and $3 \%$ respectively with increase of about $13 \%, 15 \%$ and $10 \%$ respectively with respect of $\mathrm{PC}$ at the same temperature[600Co].

Table (6) and figure (5) summarize the results of the NSC compressive strength at 7 days, for 200 Co, the PC compressive strength increases with about $18 \%$ with respect of the compressive strength at $0 \mathrm{Co}$ as for NSC with NS content $1 \%, 2 \%$ and 3\%, the compressive strength increases with about $17 \%, 15 \%$ and $16 \%$ respectively. For $400 \mathrm{Co}$, the $\mathrm{PC}$ compressive strength increases with about $12 \%$ with respect of the compressive strength at 0Co as for NSC with NS content $1 \%, 2 \%$ and 3\%, the compressive strength increases with about $16 \%, 7 \%$ and $22 \%$ respectively. . For 600 Co , the PC compressive strength decreases with about 
$13 \%$ with respect of the compressive strength at $0 \mathrm{Co}$ as for NSC with NS content $1 \%, 2 \%$ and $3 \%$, the compressive strength decreases with about $0 \%, 15 \%$ and $0 \%$ respectively.

Table (7) and figure (6) summarize the results of the NSC compressive strength at 28 days, for $200 \mathrm{Co}$, the PC compressive strength increases with about $19 \%$ with respect of the compressive strength at $0 \mathrm{Co}$ as for NSC with NS content $1 \%, 2 \%$ and 3\%, the compressive strength increases with about $30 \%, 19 \%$ and $26 \%$ respectively. For $400 \mathrm{Co}$, the PC compressive strength increases with about $6 \%$ with respect of the compressive strength at 0Co as for NSC with NS content 1\%,2\% and 3\%, the compressive strength increases with about $7 \%, 4 \%$ and $2 \%$ respectively. . For $600 \mathrm{Co}$, the PC compressive strength decreases with about $25 \%$ with respect of the compressive strength at $0 \mathrm{Co}$ as for NSC with NS content $1 \%, 2 \%$ and $3 \%$, the compressive strength decreases with about $18 \%, 25 \%$ and $22 \%$ respectively.

Table (2) : compressive strength of NSC $(\mathrm{Kg} / \mathrm{Cm} 2)$ at zero temperature

\begin{tabular}{|c|c|c|}
\hline \multirow[t]{2}{*}{ Nano silica \% } & \multicolumn{2}{|c|}{ The compressive strength[$\left[\mathrm{kg} / \mathrm{cm}^{2}\right]$ atoC ${ }^{0}$} \\
\hline & 7 days & 28Days \\
\hline 0 & 277 [control] & $400[$ control $]$ \\
\hline 1 & $281[+1.45 \%]$ & $412[+3 \%]$ \\
\hline 2 & $317[+14.45 \%]$ & $462[+15.5 \%]$ \\
\hline 3 & $303[+9.4 \%]$ & $423[+5.75 \%]$ \\
\hline
\end{tabular}

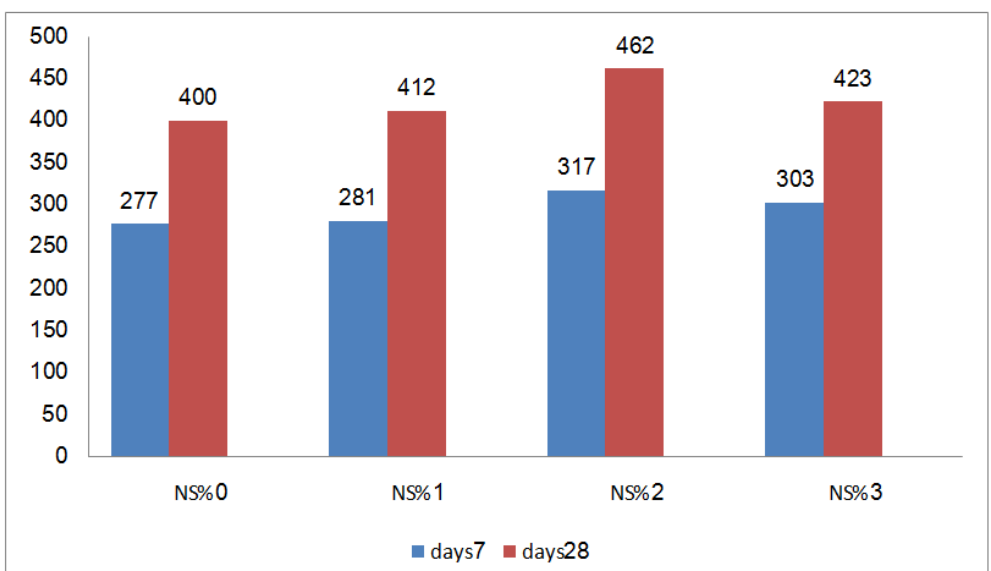

Fig. (1): The Compressive strength (Kg/Cm2) Of NSC at 0Co

Table (3): Compressive strength of NSC (Kg/Cm2) at $200 \mathrm{Co}$

\begin{tabular}{|c|c|c|}
\hline \multirow[t]{2}{*}{ Nano silica $\%$} & \multicolumn{2}{|c|}{ The compressive strength $\left[\mathrm{kg} / \mathrm{cm}^{2}\right]$ at $200 \mathrm{C}^{0}$} \\
\hline & 7 days & 28Days \\
\hline 0 & $327[$ control] & $477[$ control] \\
\hline 1 & $328[+0.30 \%]$ & $536[+12.37 \%]$ \\
\hline 2 & $365[+11.62 \%]$ & $549[+15.1 \%]$ \\
\hline 3 & $352[+7.65 \%]$ & $532[+11.53 \%]$ \\
\hline
\end{tabular}

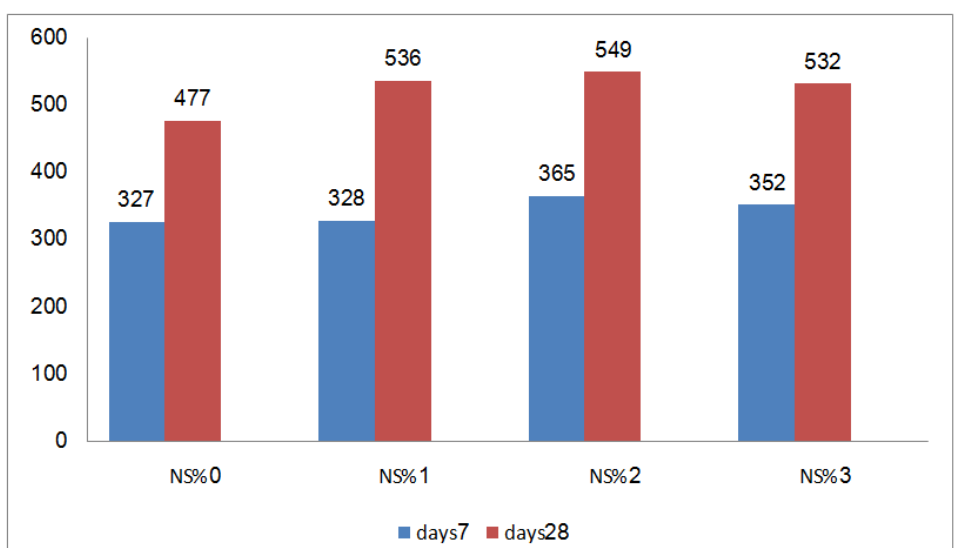

Fig. (2): The Compressive strength $(\mathrm{Kg} / \mathrm{Cm} 2)$ Of NSC at $200 \mathrm{Co}$ 
Table (4): Compressive strength of NSC $(\mathrm{Kg} / \mathrm{Cm} 2)$ at $400 \mathrm{Co}$

\begin{tabular}{|c|c|c|}
\hline \multirow{2}{*}{ Nano silica \% } & \multicolumn{2}{|c|}{ The compressive strength $\left[\mathrm{kg} / \mathbf{c m}^{2}\right]$ at 400C } \\
\cline { 2 - 3 } & 7 days & 28 Days \\
\hline 0 & $310[$ control] & $422[$ control] \\
\hline 1 & $325[+4.84 \%]$ & $442[+4.74 \%]$ \\
\hline 2 & $338[+9.03 \%]$ & $445[+5.45 \%]$ \\
\hline 3 & $369[+19.03 \%]$ & $430[+1.9 \%]$ \\
\hline
\end{tabular}

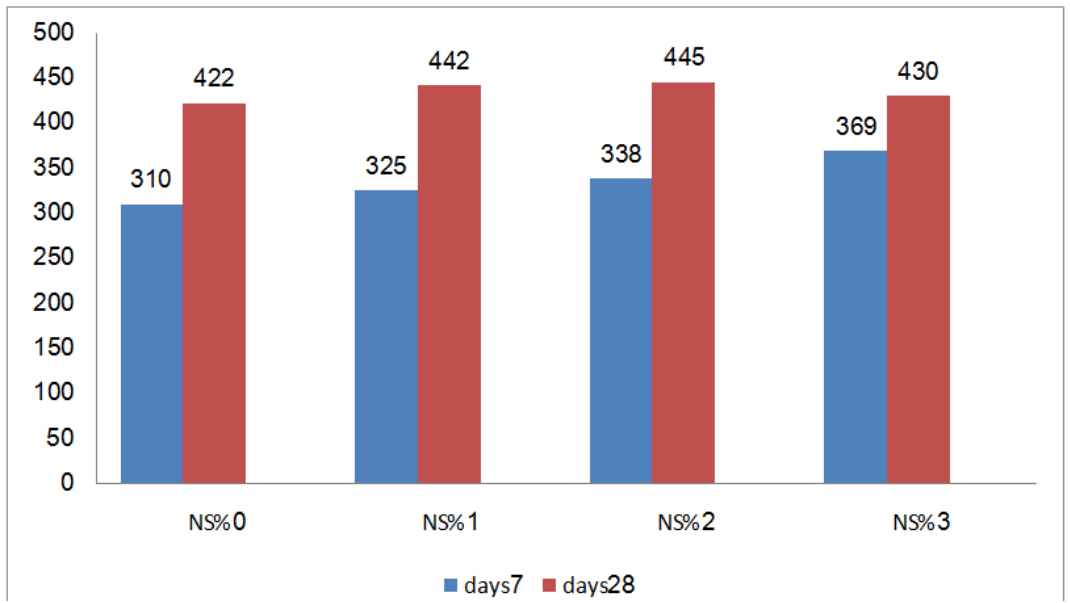

Fig. (3): The Compressive strength $(\mathrm{Kg} / \mathrm{Cm} 2)$ Of $\mathrm{NSC}$ at $400 \mathrm{Co}$

Table (5): Compressive strength of NSC (Kg/Cm2) at $600 \mathrm{Co}$

\begin{tabular}{|c|c|c|}
\hline \multirow[t]{2}{*}{ Nano silica \% } & \multicolumn{2}{|c|}{ The compressive strength $\left[\mathrm{kg} / \mathrm{cm}^{2}\right]$ at $600 \mathrm{C}^{0}$} \\
\hline & 7 days & 28 Days \\
\hline 0 & 240 [control] & 300 [control] \\
\hline 1 & $281[+17.08 \%]$ & $340[+13.33 \%]$ \\
\hline 2 & $269[+12.08 \%]$ & $345[+15 \%]$ \\
\hline 3 & $303[+26.25 \%]$ & $330[+10 \%]$ \\
\hline
\end{tabular}

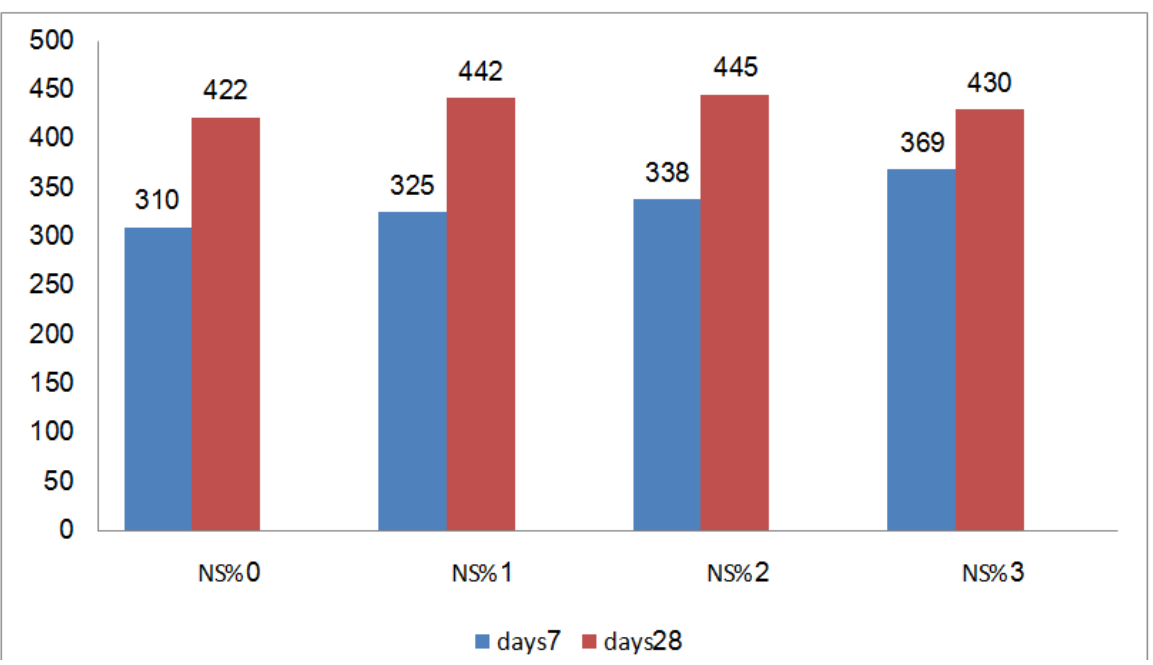

Fig. (4): The Compressive strength $(\mathrm{Kg} / \mathrm{Cm} 2)$ of NSC at $600 \mathrm{Co}$

Table (6) : Summary of compressive strength $[\mathrm{kg} / \mathrm{cm} 2]$ results of NSC at 7 days.

\begin{tabular}{|c|c|c|c|c|}
\hline \multirow[t]{2}{*}{ Nano silica \% } & \multicolumn{4}{|c|}{ The compressive strength $\left[\mathrm{kg} / \mathrm{cm}^{2}\right]$ at } \\
\hline & $\mathbf{0 C}^{0}$ & $200 \mathrm{C}^{0}$ & $400 \mathrm{C}^{0}$ & $600 \mathrm{C}^{0}$ \\
\hline $\mathbf{0}$ & $277[$ control] & $327[+18.05 \%]$ & $310[+11.91 \%]$ & $240[-13 \%]$ \\
\hline 1 & $281[$ control] & $328[+16.73 \%]$ & $325[+15.66 \%]$ & $281[0 \%]$ \\
\hline 2 & 317 [control] & $365[+15.14 \%]$ & $338[+6.62 \%]$ & $269[-15.1 \%]$ \\
\hline 3 & 303 [control] & $352[+16.17 \%]$ & $369[+21.78 \%]$ & $303[0 \%]$ \\
\hline
\end{tabular}




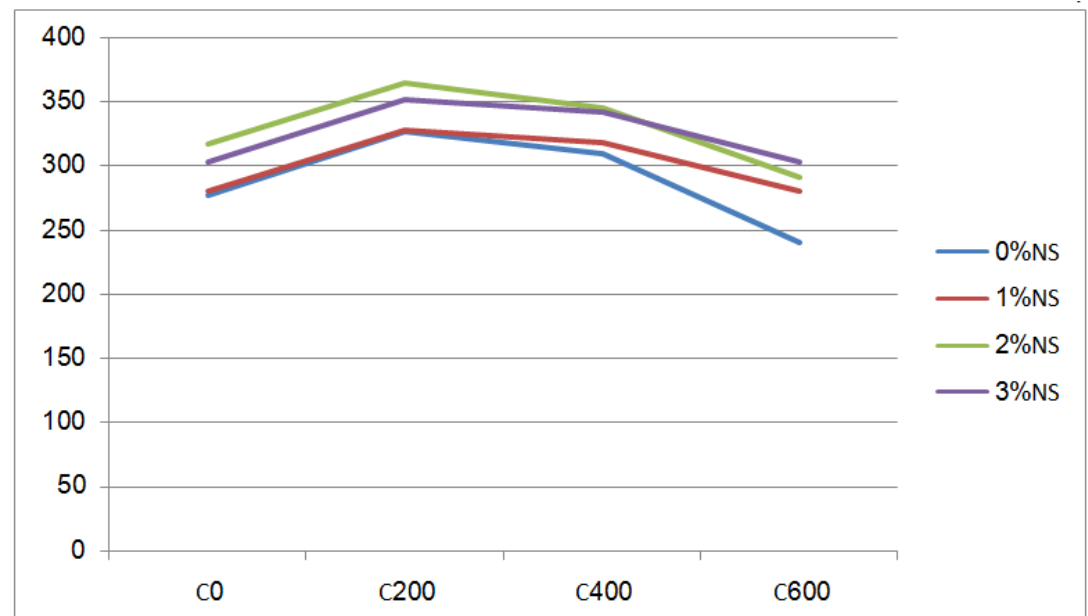

Fig. (5): The effect of high temperatures on the concrete mixes at 7 days age

Table (7) : Summary of compressive strength[kg/cm2] results of NSC at 28days.

\begin{tabular}{|c|c|c|c|c|}
\hline \multirow[t]{2}{*}{ Nano silica \% } & \multicolumn{4}{|c|}{ The compressive strength $\left[\mathrm{kg} / \mathrm{cm}^{2}\right]$ at } \\
\hline & $0 \mathrm{C}^{0}$ & $200 \mathrm{C}^{0}$ & $400 \mathrm{C}^{0}$ & $600 \mathrm{C}^{\circ}$ \\
\hline $\mathbf{0}$ & $400[$ control] & $477[+19.25 \%]$ & $422[+5.5 \%]$ & $300[-25 \%]$ \\
\hline 1 & 412 [control] & $536[+30.1 \%]$ & $442[+7.28 \%]$ & $340[-17.5 \%]$ \\
\hline 2 & 462 [control] & $549[+18.83 \%]$ & $445[-3.67 \%]$ & $345[-25.3 \%]$ \\
\hline 3 & 423 [control] & $532[+25.77 \%]$ & $430[+1.65 \%]$ & $330[-22 \%]$ \\
\hline
\end{tabular}

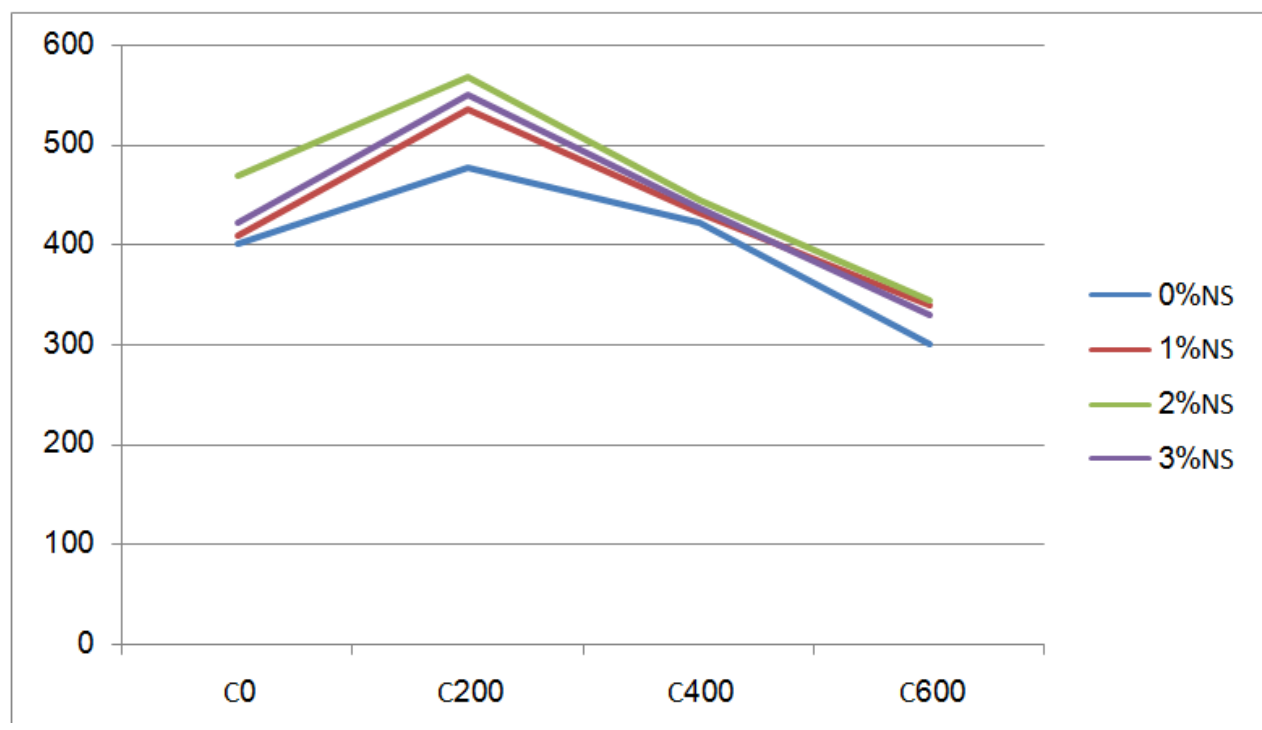

Fig. (6): The effect of high temperatures on the concrete mixes at 28 days age

\section{Conclusions}

1)At room temperature, the replacement of cement by $1 \%, 2 \%$ and $3 \%$ NS increased the 7 days compressive strength approximately $2 \%, 14 \%$ and $9 \%$ respectively compared to PC.

2) At room temperature, the replacement of cement by $1 \%, 2 \%$ and $3 \%$ NS increased the 28 days compressive strength approximately $3 \%, 16 \%$ and $6 \%$ respectively compared to PC.

3) After subjected to $200 \mathrm{Co}$, significant increase occurred in the compressive strength of normal and NS concretes at 7 days ,the increase in compressive strength was $18 \%, 17 \%, 15 \%$ and $16 \%$ for PC and NSC [1\%, $2 \%, 3 \%$ ] respectively with respect of the compressive strength at $0 \mathrm{Co}$.

4) After subjected to $200 \mathrm{Co}$, significant increase occurred in the compressive strength of normal and NS concretes at 28 days ,the increase in compressive strength was $19 \%, 30 \%, 19 \%$ and $26 \%$ for PC and NSC [1\%, $2 \%, 3 \%$ ] respectively with respect of the compressive strength at $0 \mathrm{Co}$.

5) After subjected to $400 \mathrm{Co}$, significant increase occurred in the compressive strength of normal and NS concretes at 7 days, the increase in compressive strength was $12 \%, 16 \%, 7 \%$ and $22 \%$ for PC and NSC [1\%, $2 \%, 3 \%$ ] respectively with respect of the compressive strength at $0 \mathrm{Co}$. 
6) After subjected to $400 \mathrm{Co}$, slightly increase occurred in the compressive strength of normal and NS concretes at 28 days ,the increase in compressive strength was $6 \%, 7 \%, 4 \%$ and $2 \%$ for PC and NSC [1\%, $2 \%, 3 \%$ ] respectively with respect of the compressive strength at $0 \mathrm{Co}$.

7) After subjected to $600 \mathrm{Co}$, significant decrease occurred in the compressive strength of normal and NS concretes at 7 days ,the decrease in compressive strength was $13 \%, 0 \%, 15 \%$ and $0 \%$ for PC and NSC [1\%,2\%, $3 \%$ ] respectively with respect of the compressive strength at $0 \mathrm{Co}$.

8) After subjected to $600 \mathrm{Co}$, significant decrease occurred in the compressive strength of normal and NS concretes at 7 days ,the decrease in compressive strength was $25 \%, 18 \%, 25 \%$ and $22 \%$ for PC and NSC [1\% , $2 \%, 3 \%$ ] respectively with respect of the compressive strength at $0 \mathrm{Co}$.

\section{References}

[1] Suryawanshi Y.R. and Sagar Umbare. Effect of Variation of Elevated Temperature on Compressive Strength of Metakaolin Concrete: Literature Study. International Jour. of Current Eng. and Technology 2015, Vol.5, No.4 2-

[2] S.H. Chowdhury. Effect Of Elevated Temperature Mechanical Properties Of High Strength Concrete Australasian Conference[23rd] on the Mechanics of Structures and Materials (ACMSM23) , 9-12 Dec. 2014.

[3] Husem, M. The Effects Of High Temperature On Compressive And Flexural Strengths Of Ordinary And High Performance Concrete, Fire Safety Jour. 2006, Vol. 41, No. 2, pp. 155-163.

[4] Benhood A. and Ziari H. ,Effects Of Silica Fume Addition And Water To Cement Ratio On The Properties Of High Strength Concrete After Exposure To High Temperatures, Cem. and Conc. Composites jour. 2008, Vol. 30, pp. 106-112.

[5] ACI committee 363. State-of-the-Art Report on High Strength Concrete, American Conc. Instit. 1993, Detroit, USA.

[6] Cioni P., Croce P. and Salvatore W. Assessing fire damage to R.C. elements Fire Safety Journal 2001, Vol. 36, pp. 181-199.

[7] Cho-Liang, T. Chiang, C. Yang C. and Chun-Ming C. Tracking concrete strength under variable high temperature, ACI Materials Jour. 2005, Vol. 102, No. 5, pp. 322-329.

[8] Castillo C. and Durrani A.J. Effect of transient high temperature on high strength concrete, ACI Materials Jour. 1990, Vol. 87, No. 1 , pp. 47-53.

[9] Knaack A., Kurama Y., and Kirkner D. Compressive strength relationships for concrete under elevated temperatures, ACI Materials Jour. 2010, Vol. 107, No. 2, pp. 164-175.

[10] Arioz O. Effects Of Elevated Temperatures On Properties Of Concrete, Fire Safety Jour. 2007, Vol. 42, No. 8, pp. 516-522.

[11] Phan L.T. and Carino, N.J., Review Of Mechanical Properties Of HSC At Elevated Temperature, Jour. of Mater. in Civil Eng. 2007, American Society of Civil Engineers, vol. 10 (1)(February, 1998)pp. 58-64.

[12] Phan, L.T.; Carino, N.J., 'Mechanical Properties of High Strength Concrete at Elevated Temperatures', NISTIR 6726, Build. and Fire Res. Lab., National Instit. of Stand. and Techn., Maryland, March 2001.

[13] Phan L.T., Carino N.J., Effects Of Test Conditions And Mixture Proportions On Behavior Of High Strength Concrete Exposed To High Temperatures, ACI Materials Jour. 2002 , American Concrete Institute, vol. 99 (1) pp.54-66.

[14] Phan L.T., Lawson J.R. ,Davis F.R., Effects Of Elevated Temperature Exposure On Heating Characteristics, Spalling , And Residual Properties Of High Performance Concrete, RILEM Mater. and Structures Jour. 2001, vol. 34 (236) pp. 83-91.

\footnotetext{
K.I.M.Ibrahim. "The Effect of High Elevated Temperatures on Nano Silica High Strength Concrete [NSHSC]." IOSR Journal of Mechanical and Civil Engineering (IOSR-JMCE) 14.4 (2017): 61-66.
} 